are up-to-date as of October 1952. The bibliographies include books and articles published as late as 195I, although Kirchner does not seem to have access to complete files of all the more important American, English, and Scandinavian books and journals published in the field of the book arts during the last decade and a half.

The articles on libraries and librarianship have been restricted to a few comprehensive historical surveys, and the articles on palaeography have been cut down considerably. Certain other fields such as journalism, library architecture and administration, and history of writing have been eliminated. The many entries under cities in the Lexikon des gesamten Buchwesens have been largely eliminated and the information included in the articles under the names of countries and provinces (although there are no entries under any states of the American republics). Bibliographies, in general, are somewhat smaller; but in a work of this sort selection is the most important element in giving additional references. It is unfortunate that articles are not signed, but Kirchner states there are "important reasons" for omitting names of authors. The list of his collaborators in the preface is a sufficient guarantee of the reliability of the work.

Kirchner has done very well by the world of the book in America and seems to have covered its most important aspects. His statement that the John Carter Brown Library is "in the University Library in Providence" (p. IIo) is misleading, and the Huntington Library was not given to the State of California, (p. 337). Kirchner is not always meticulously careful with his accents in such languages as Portuguese and Icelandic, and there are some misprints. For example, read Capella on p. 44 where the name Martianus Copella appears; 1820 , not 1920 , as the date of the founding of the University of Michigan (p. I8); and 195I, not 193I, as the date of publication of Dagher's directory of libraries in the Near East.

Such criticism, however, is hardly justified from an English-speaking person. We should reserve any critical comments until we have produced a work such as the Lexikon des Buchwesens or the great Nordisk Leksikon for Bogvaesen (now as far as "Litografi") being published by the Nyt Nordisk Forlag Arnold Busck in Copenhagen.

The second and concluding volume of the
Lexikon des Buchwesens will be available later this year.-Lawrence $S$. Thompson, University of Kentucky.

\section{Government Information}

Government Information and the Research Worker: Lectures delivered at a Vacation Course of the University of London School of Librarianship and Archives in April, 195I. Ed. with an Introduction by Ronald Staveley. B.A., F.L.A. London, Library Assoc., 1952. vi, 228p. 24s.

For a long time the users of British government publications have found it easy to locate clearly written and accurate descriptions of Parliamentary Papers, Statutes, Gazettes, etc., but when it came to finding descriptions of the non-parliamentary publications of ministries and other administrative bodies very little satisfactory material seemed to be available. Therefore this new book which is largely, though not exclusively, devoted to non-parliamentary publications should be welcomed by students, librarians and research workers. Though not a systematic manual nor complete in its coverage, it will answer many of the questions concerning the functions of government departments and the series they publish which naturally arise in the minds of readers and it makes an excellent addition to a small group of works ${ }^{1}$ which every general research library should contain.

Five general lectures furnished an introduction to this series. The first by E. M. Nicholson, secretary, Office of the Lord President of the Council, was on "The Government and Research." In the second, Dr. W. R. Francis of the Department of Scientific and Industrial Research described "the government agencies and departments in which scientific research is undertaken and sponsored." These first two lectures are not printed in this book because the information they contained is adequately treated in a I95 I Treasury publication entitled Government Scientific Organization in the Civilian Field: a Review Prepared For the Lord President of the Council by the Advisory Council on Scientific Policy. The third of these preliminary lectures was on

1 E.g., Ford, Percy, and Ford, G. A Breviate of Parliamentary Papers: I917-1939. I951; Harrocks, Sidney. The State as a Publisher. I952 (Library Association Pamphlet no. 1o); Temperley, Harold, arary Association Pamphlet no. ro); Temperley, Harold, Bluc Books: I8I4-I9I4. I938. 
"His Majesty's Stationery Office" given by Mr. Cox, the deputy comptroller. It furnishes an excellent brief account of the policies and activities of this chief publisher and distributor of British official documents. The next dealt with the plans and publications of "The Interdepartmental Committee on Social and Economic Research." The concluding lecture of the general series by Sir Hilary Jenkinson on "The Problem of Elimination in the Records of Public Departments" bears a close relationship to the information supplied by subsequent papers on the unpublished data in departmental files which may interest research workers.

Twenty-two chapters, each dealing with the publications of a separate ministry, board, office or council, 'follow these preliminary chapters. No two are exactly alike but most of them begin with a short history of the administrative body, followed by an account of its functions and duties and the publications which grow out of these. Series, periodicals, reports and other outstanding separate publications are treated. Important "command papers" including the reports of royal commissions, select committees and annual reports are mentioned and sometimes described. Most of the authors who lectured on the works published by individual departments were librarians, and in response to a request by the organizers of this course they tell whether their libraries are open to ordinary students and investigators and what unpublished records, statistical material and other research data their departments contain which would be available for research purposes. This latter type of information would be more frequently useful to the British than to the American student.

While the above description is fairly accurate, it represents the more informative and detailed report. The lectures given were somewhat uneven in quality, some giving a good deal of information on publications, others very little. Those on the Ministry of Agriculture and Fisheries, the Medical Research Council, the Department of Scientific and In- dustrial Research and the Ministry of Supply give less data on publications than one might desire. On the other hand several chapters, including those on the Ministries of Health, Fuel and Power, Town and Country Planning and that on the Colonial and Commonwealth Relations Offices, give excellent accounts of organization and publications and should be most helpful to investigators and students. Some of the newer agencies such as the Information Division of the Treasury, the Social Survey and the Technical Information and Documents Unit of the Board of Trade are well described and their publications noted.

Only civil departments are treated-none of the publications of the Admiralty, the War Office, the Air Ministry or the Ministry of Civil Aviation receive attention. Not even the long series of the Aeronautical Research Council are included. The only publications of the Geological Survey which are given are the new maps it is contributing to the National Atlas. No historical publications are treated and the 195I Census, taken in the same month in which the Course convened, is not described.

The blue cloth binding lettered in gold is attractive but the cover already shows signs of coming loose and will not stand up under continuous use. The print is readable except in the chapters in which detailed lists of publications have been added by the lecturers in the course of revision of their addresses. These lists are in very fine print and are not too easily read.

In conclusion it may be stated that one of the strongest points in favor of the work is its unquestionable authority. Each author is an officer of the governmental unit for which he speaks and has an intimate, first-hand acquaintance with its organization, activities and publications. No general compiler of a more systematic manual could possibly know all these bodies so well. For this reason the book would still continue to be valuable even if a more systematic manual should later become available.-Rose B. Phelps, University of Illinois Library School. 